\title{
BIOACTIVITY OF GINGER, Zingiber officinale RHIZOMES EXTRACT AGAINST TWO-SPOTTED SPIDER MITE, Tetranychus urticae KOCH (ACARI: TETRANYCHIDAE) AND CHARACTERIZATION OF ITS VOLATILE COMPONENTS USING GC/MS TECHNIQUE. Shaker, N. O. ${ }^{1}$; M. E. El-Naggar ${ }^{2}$; M. M. El-Sawey ${ }^{1}$ and H. N. Abd El-Rahman ${ }^{2}$ \\ 1. Applied Organic Chemistry, Fac. of Sci. (Girls), Al-Azhar University. 2. Plant protection Res. Institute, ARC, Dokki, Giza, Cairo.
}

\begin{abstract}
Ginger rhizomes extract was obtained by using a mixture of organic solvents,( hexane, acetone and ethanol )of equal proportions (1:1:1). Its volatile components were characterized and identified by GC/MS technique giving thirteen compounds. Also, bioactivity of ginger extract against adults and larval stage of $T$. urticae was evaluated. Ginger extract showed cumulative mortality of adults more than $20.00 \%$ at 3 rd day post treatment at different concentrations. The cumulative mortality increased to range between $43.33-66.67 \%$ and $46.67-83.33 \%$ at 5 th and 7 th day post treatment, respectively at different concentrations. Also, data showed that ginger extract had a mild effect against adults of $T$. urticae with $\mathrm{LC}_{50}$ of $1540 \mathrm{ppm}$ and $\mathrm{LC}_{90}$ of $10100 \mathrm{ppm}$.

The larval stage showed more susceptibility than their adults to ginger extract using the same concentrations and exposure time. It showed mortality percentage of $90.00 \%$ at $7^{\text {th }}$ day of treatment with the higher concentration of $6000 \mathrm{ppm}$. Also, it showed $\mathrm{LC}_{50}$ of $928 \mathrm{ppm}$ and $\mathrm{LC}_{90}$ of $5330 \mathrm{ppm}$.

Keywords: Tetranychus urticae, Zingiber officinale, GC/MS analysis of ginger extract.
\end{abstract}

\section{INTRODUCTION}

The two spotted spider mite, Tetranychus urticae, is one of the most important pests of fruit, vegetables and ornamental plants world wide (Johnson and Lyon, 1991). Damage by T. urticae can cause direct effects including small spots on the leaf due to chlorophyll depletion, webbing, defoliation, necrosis in young leaves and stems; indirect effects including decreased photosynthesis and transpiration, and finally death of the whole plant (Badawy et al. 2010). Chemical insecticides result in environmental degradation in addition to accumulation of toxicants as residual deposits in non-target species. Natural products of plant origin with insecticidal properties have been tried in the recent past for control of variety of insect pests and vectors (Saxena,1983 and Klocke,1987). It has been researched lately, demand for new plants with metabolic molecules such as terpenes, alkaloids and phenolic compounds, that can replace chemicals or with low or no residual power and reduce the impact to environment (Ootani et al., 2013). The goal of this study was to find new materials for potential use in controlling T. urticae. GC-MS analysis was used to identify the main volatile constituents 
Shaker, N. O. et al.

of ginger rhizomes extract, then, tested for its acaricidal effect in the laboratory.

\section{MATERIALS AND METHODS}

\section{Rearing of the two spotted spider mite, T. urticae:}

A pure culture of the spider mite was maintained on castor leaves placed upside down in Petri-dishes $(20 \mathrm{~cm}$ in diameter) filled with water saturated cotton-wool. Infested leaves and tap-water were changed as necessary.

\section{Extraction of the active fractions from tested plants:}

Rhizomes of Zingiber officinale were grinded into fine powder by using electric mill. The powder of ginger rhizomes was weighted then soaked in a mixture of hexane, acetone and ethanol solvents of equal proportions (1:1:1) in a flask for about seven days then shacked well, filtered and washed by the same solvent system three times. The solvent was evaporated and the crude extract was kept in a deep freezer until use.

\section{Chemical Study:}

A sample of ginger extract was analyzed by GC/MS technique for characterization and identification of its volatile components. GC/MS analysis of the volatile fractions were performed on a Varian GC interfaced to Finnegan SSQ 7000 Mass selective Detector (SMD) with ICIS V2.0 data system for MS identification of the GC components. The column used was DB-5 (J \& W Scientific, Folosm, CA) cross-linked fused silica capillary column ( $30 \mathrm{~m}$. long, $0.25 \mathrm{~mm}$. internal diameter) coated with poly dimethyl-siloxane $(0.5 \mu \mathrm{m}$. film thickness). The oven temperature was programmed from $50 \mathrm{oC}$ for $3 \mathrm{~min}$., at isothermal, then heating by $7 \mathrm{oC} / \mathrm{min}$. to $250 \mathrm{oC}$ and isothermally for $10 \mathrm{~min}$. , at $250 \mathrm{oC}$. Injector temperature was $200 \mathrm{oC}$ and the volume injected was $0.5 \mu \mathrm{l}$. Transition-line and ion source temp. were $250 \mathrm{oC}$ and $150 \mathrm{oC}$, respectively. The mass spectrometer had a delay of $3 \mathrm{~min}$. to avoid the solvent plead and then scanned from $\mathrm{m} / \mathrm{z} 50$ to 300 . lonization energy was set at $70 \mathrm{eV}$. (Faculty of Pharmacy, Mansoura Univ.).

\section{Bioassay Study:}

Petri-dishes were filled with cotton wool, saturated with water and then covered with tissue papers. Three discs, each of $2.5 \mathrm{~cm}$ in diameter of castor leaves, were carefully washed, sterilized, dried and placed upside down on the tissue papers in each dish. A thin film of water was left around the edge of the leaf discs to act as a barrier to prevent escaping of the mite survivors, and the cotton pad was moistened daily. Ten adult females (or ten newly hatched larvae in case of treatment of larvae) similar in shape, size and age were transferred on each disc. These discs were sprayed with tested plant extracts. Untreated three discs (control) for each experiment were sprayed only with water and $0.05 \%$ aquous Tween 80 . The Petri-dishes were placed in an incubator at $27 \pm 1 \mathrm{C}^{\circ}, 75 \pm 2 \% \mathrm{RH}$. , and photoperiod 16:8 hrs (L: D).Data was recorded daily and the experiment continued for seven days (Ibrahim, 2007). 
At the end of this period, the average of mortality percentages of spider mite was estimated and corrected using Abbott's formula (1925). The corrected mortality percentage of each extract was statistically calculated according to Finney (1971). From which the corresponding concentration probit lines (LC-p lines) were estimated in addition to determination of $\mathrm{LC}_{50}$ ,LC 90 and slope values of tested plant extract also estimated.

\section{RESULTS AND DISCUSSION}

\section{Chemical Study:}

Ginger powder which weighted $500 \mathrm{gm}$ gave $23.28 \mathrm{gm}$ of crude extract. When this extract analyzed by the GC/MS chromatogram showed thirteen peaks corresponding to thirteen compounds. These compounds were characterized by comparing their mass spectra with those of their analogous reported by NIST library. The obtained results were reported in Table (1).

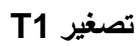


Shaker, N. O. et al.

\section{Bioassay Study:}

Efficiency of ginger extract against $T$. urticae:

Data in Table (2) and Fig. (1\&2) showed that cumulative mortality percent of both of adults and larvae increased with increasing the tested extract concentrations, and with increasing the exposure time.

Table (2): Efficiency of ginger rhizomes extract against adults \& larvae of $T$. urticae under laboratory conditions of $27 \pm 1 \mathrm{C}^{0}$ and 75 $\pm 2 \% \mathrm{RH}$.

\begin{tabular}{|c|c|c|c|c|c|c|c|}
\hline \multirow[t]{2}{*}{ Treatment } & \multirow[t]{2}{*}{ Conc. ( ppm) } & \multicolumn{3}{|c|}{$\begin{array}{l}\text { Mortality \%at indicated } \\
\text { day after treatment. }\end{array}$} & \multirow[t]{2}{*}{ LC50 } & \multirow[t]{2}{*}{ LC90 } & \multirow[t]{2}{*}{ Slope } \\
\hline & & 3 day & 5 day & 7day & & & \\
\hline \multirow{4}{*}{ Adults } & 1000 & 20 & 43.33 & 46.67 & \multirow{4}{*}{1540} & \multirow{4}{*}{10100} & \multirow{4}{*}{1.57} \\
\hline & 2000 & 43.33 & 50.00 & 60.00 & & & \\
\hline & 4000 & 36.67 & 60.00 & 70.00 & & & \\
\hline & 8000 & 46.67 & 66.67 & 83.33 & & & \\
\hline \multirow{4}{*}{ Larvae } & 1000 & 20.00 & 50.00 & 53.33 & \multirow{4}{*}{928} & \multirow{4}{*}{5330} & \multirow{4}{*}{1.68} \\
\hline & 2000 & 26.67 & 63.33 & 76.67 & & & \\
\hline & 4000 & 43.33 & 80.00 & 83.33 & & & \\
\hline & 6000 & 56.67 & 86.67 & 90.00 & & & \\
\hline
\end{tabular}

Regarding to adults, ginger extract showed cumulative mortality more than $20.00 \%$ at 3 rd day post treatment at different concentrations. The cumulative mortality increased to range between $43.33-66.67 \%$ and 46.67 $83.33 \%$ at 5 th and 7 th day post treatment, respectively at different concentrations. Also, data showed that ginger extract had a mild effect against adults of $T$. urticae with $\mathrm{LC}_{50}$ of $1540 \mathrm{ppm}$ and $\mathrm{LC}_{90}$ of $10100 \mathrm{ppm}$.

The larval stage showed more susceptibility than their adults to ginger extract using the same concentrations and exposure time. It showed mortality percentage of $90.00 \%$ at $7^{\text {th }}$ day of treatment with the higher concentration of $6000 \mathrm{ppm}$. Also, it showed LC $\mathrm{LC}_{50}$ of $928 \mathrm{ppm}$ and $\mathrm{LC}_{90}$ of $5330 \mathrm{ppm}$. 


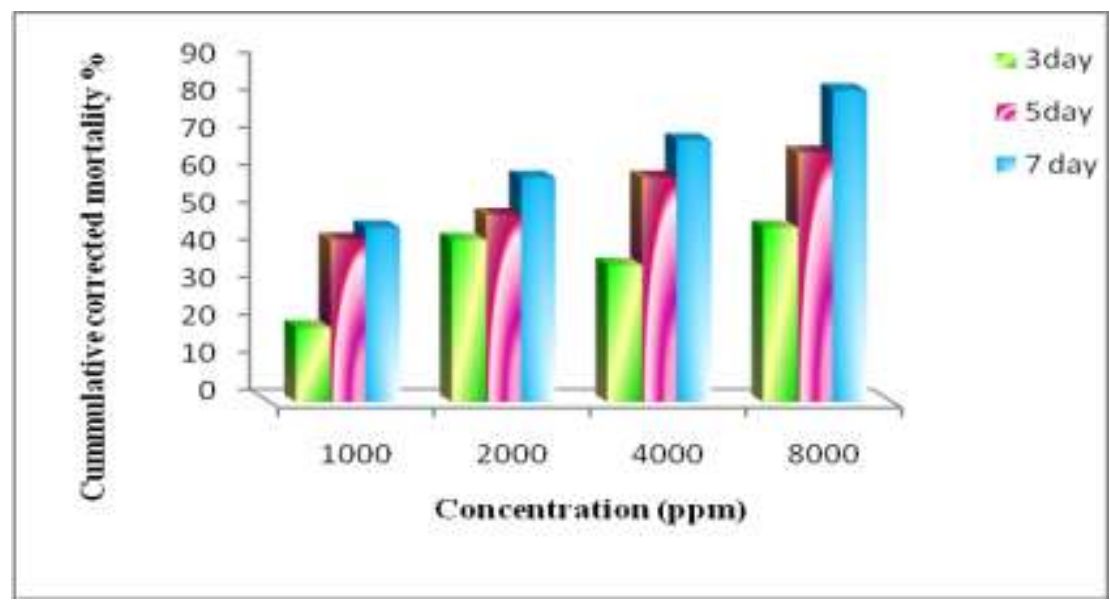

Fig.(1) : The cumulative mortality $\%$ of ginger extract against adults of $T$. urticae.

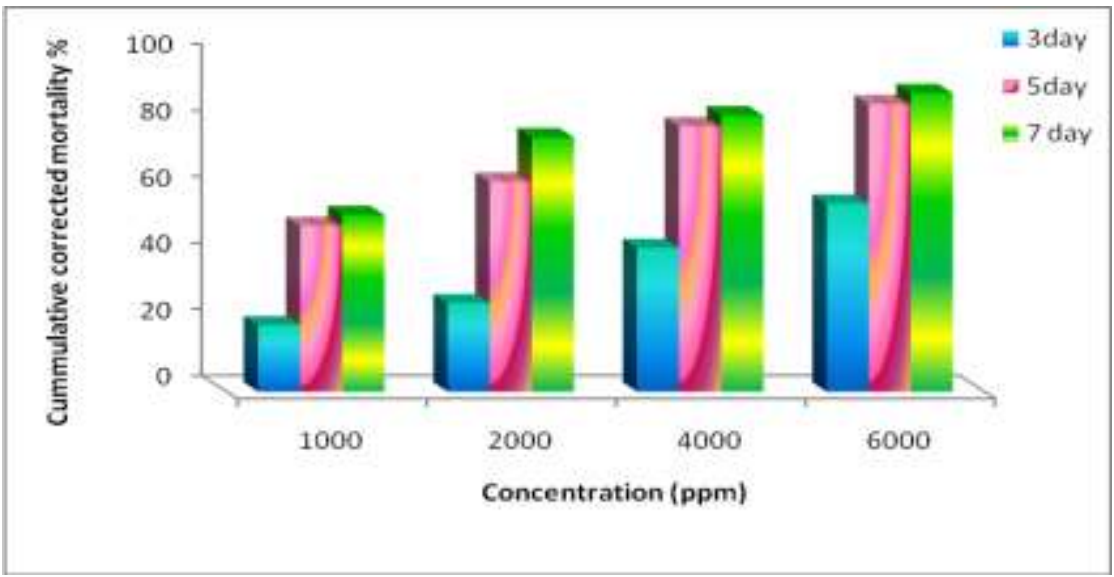

Fig.(2) : The cumulative mortality $\%$ of ginger extract against larval stage of $T$. urticae.

\section{REFERENCES}

Abbott, W. S. (1925). A method for computing the effectiveness an insecticide. J. Econ. Entomol., 18: 265-267.

Badawy, M. El. ; El-Arami, S. A. A. ; Abdelgaleil, S. A. M. (2010). Acaricidal and quantitative structure activity relationship of monoterpenes against the two-spotted spider mite, Tetranychus urticae. Exp Appl Acaro,I 52:261-274.

Finney, D. J. (1971). Probit analysis. A Statistical Treatment of the Sigmoid Response Curve. 7th Ed., Cambridge Univ. Press, England. 


\section{Shaker, N. O. et al.}

Ibrahim, H. Y. E. (2007). Evaluation of some entomopathogens of certain vegetable pests. M. Sci. Thesis. Fac. Sci. Mansoura Univ. Egypt.

Johnson, W. T. and Lyon, H. H. (1991). Insects that feed on trees and shrubs (2nd edn.), comostock publishing/ cornel University press, Ithaca, NY, pp. 468-470.

Klocke, J. A. (1987). Natural plant compounds useful in insect control. J. Americn Chem. Society,330(36):396-415.

Ootani, M. A.; Aguiar, R. W. S.; Ramos, A. C. C.; Brito, D. R.; Silva, J. B. and Cajazeira, J. P. (2013). Utilizaca o de oleos essenciais na agricultura. J. Bio. Tech. Biodivesity, 4(2).

Saxena, R. C. (1983). Naturally occurring pesticides and their potential, p: 143 In: Chemistry and World Food Supplies: The New Frontiers Chemrawn II. L. W. Shemilt, Pergamon Press.

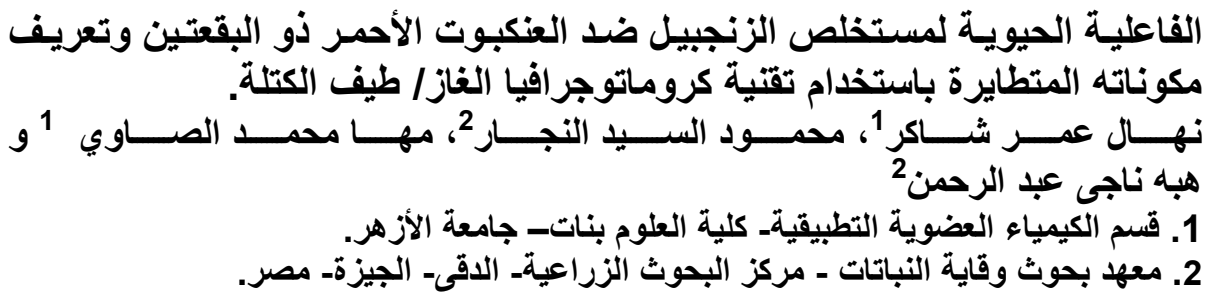

تم الحصول على مستخلص الزنجبيل باستخدام الدذيبات العضوية (هكسان، أسيتون،و إيثانول )

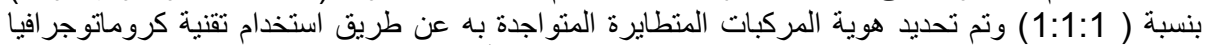

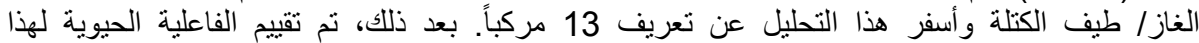

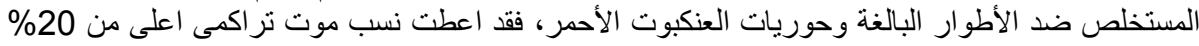

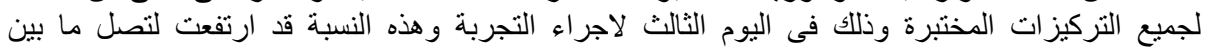

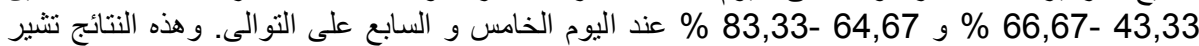

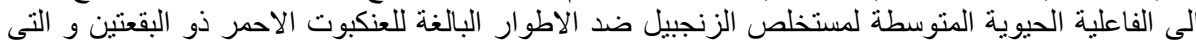

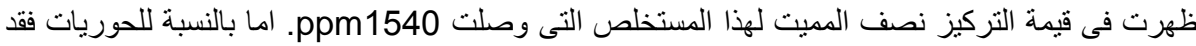

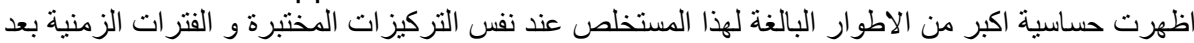

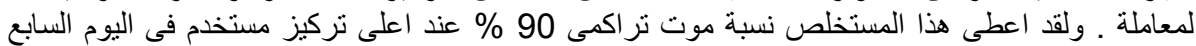

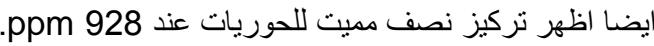

كلبة الزراعة - جامعة المنصورة

كلية العلوم- جامعة المنة جلمورة المنصورة
قام بتحكيم البحث

أ.د / عبد البديع عبد الحميد غاتم البحت

أ.د / عبد الرؤوف محمد سلام علدي عالم 